\title{
Characterization of Foams Obtained from Cassava Starch, Cellulose Fibres and Dolomitic Limestone by a Thermopressing Process
}

\author{
Vivian Consuelo Reolon Schmidt and João Borges Laurindo* \\ Departamento de Química e Engenharia de Alimentos; Universidade Federal de Santa Catarina; 88040-900; \\ Florianópolis - SC - Brasil
}

\begin{abstract}
Cassava starch, dolomitic limestone and eucalypt cellulose fibres were used to prepare foam trays that could be used to pack foodstuffs. The influence of the cellulose fibre concentration in the composite formulation was investigated using 5, 10, 15, 20, 30 and 40\% of fibres. The results indicated that an increase in cellulose fibre concentration promoted a decrease in density and tensile strength of the foam samples. The tensile strength at break for foam trays containing $5 \%$ of cellulose fibres was 3.03MPa, whilst the commercial trays of expanded polystyrene used to pack foods in supermarkets presented a tensile strength of $1.49 \mathrm{MPa}$. The elongation at break of the foam trays obtained in this work varied slightly with increase in cellulose fibre concentration, the values being about $20 \%$ lower than the elongation at break observed for commercial foam trays of expanded polystyrene. Thus, the materials developed in this work represented a possible alternative to the use of EPS foam trays for packing dry foods. The trays' properties need to be improved for their use with moist foods.
\end{abstract}

Key words: biodegradable trays, cassava starch, eucalypt cellulose fibres, limestone, guar gum, thermoprocessing

\section{INTRODUCTION}

The main characteristics of petroleum-based plastics are their low cost, ease of processing, wide applicability and durability. They are hydrophobic materials not allowing microbial action and, therefore, take hundreds of years to decompose (Leite et al., 1999). The use of environmentallyfriendly materials is an alternative to petroleumbased materials. When biodegradable materials are discarded in the environment, they are easily degraded into simpler compounds that can be metabolised by microorganisms such as bacteria, yeast and fungi (Gould et al., 1990; Vinhas et al., 2007).

In order to decrease the negative impact and volumes of solid residues in the environment caused by plastic packaging, new biodegradable materials have been developed. Composite foams have been prepared from vegetable raw materials, such as starch, fibres and vegetable protein, which are renewable resources widely found in nature, and of relatively low cost (Da Róz et al., 2001; Shogren et al., 2002; Matsui et al., 2004; Soykeabkaen et al., 2004).

Previous studies have shown that heating

*Author for correspondence: joao@enq.ufsc.br 
starch/water mixtures under pressure in closed moulds can produce starch foams (Tiefenbacher, 1993; Lawton et al., 1998; Shogren et al., 1998; Glenn et al., 2001a; Lawton et al., 2004; Soykeabkaen et al., 2004). Materials obtained from starch are brittle and sensitive to water, requiring further treatment or the addition of other ingredients (such as fibres for example) to improve their tensile properties, flexibility and resistance to direct contact with water. Improvement of the properties of starch/water composite foams was achieved by casting them together with polyesters (Lawton et al., 1998; Shogren et al., 1998), or by adding polyvinyl alcohol (PVOH) to the starch/water mixture before the heat treatment. Minerals, wood, fibres, modified starch and hydrophobic compounds such as vegetable oils, have also been added to the mixtures to improve their strength and the elongation of corn starchbased composite foams (Andersen and Hodson, 2001a; Andersen et al., 2001b; Shogren et al., 2002; Soykeabkaew et al., 2004). Glenn et al., (2001b) and Soykeabkaew et al. (2004) reported that the strength and flexibility of starch composite foams could be improved by incorporating wood fibres (such as aspen fibres) or jute and flaxreinforced fibres. Fibre addition improves the flexibility and elongation at break of starch-based composite foams (Shogren et al., 2002). Matsui et al., (2004) reported that the addition of Kraft paper fibres to composites of cassava bagasse led to more resistant materials.

Preliminary tests performed in this work showed that materials prepared just with cassava starch did not form a rigid structure that could be handled and used as trays. Thus, the objective of this work was to prepare and to evaluate the properties of foam composites, obtained by thermopressing of mixtures of cassava starch, eucalypt cellulose fibres and dolomitic limestone. Moreover, tests with cheese, ham and frozen foods were performed for a preliminary evaluation of using these materials for packing foods.

\section{MATERIAL AND METHODS}

The raw materials used to obtain the starch-based foam trays were cassava starch, eucalypt cellulose fibres and dolomitic limestone. Unmodified cassava starch was purchased from Yoki Alimentos S.A., Brazil. Eucalypt cellulose pulps were softwood short fibres with $1.2 \mathrm{~mm}$ and obtained from Klabin S.A., Brazil. Dolomitic limestone (mesh size number $50-0,3 \mathrm{~mm}$ ) was purchased from local retail stores in Florianópolis, Brazil. Guar gum was purchased from Nicrom Química Ltda, Brazil. Magnesium stearate was purchased from Quimidrol Ltda, Brazil.

To prepare the mixture, the water and cellulose fibres were mixed for 5 minutes in a mechanical stirrer (Fisaton, Brazil, mod 713D), and the limestone then added and mixed for a further 3 minutes. Guar gum $(1 \%$, w/w) was also added to avoid settling of the solids, and magnesium stearate $(1.5 \%, \mathrm{w} / \mathrm{w})$ to facilitate the removal of the foam from the mould (Fig. 1). Different samples were obtained by varying the cellulose fibre concentration in the mixture using $5,10,15$, 20,30 and $40 \%$. The ratio between starch and limestone was maintained at $1: 1$, only varying the proportion of fibre as shown in Table 1 .

Table 1- Composition of the mixtures used to prepare the foam trays.

\begin{tabular}{cccccc}
\hline Formulation $\mathbf{N}^{\circ}$ & $\begin{array}{c}\text { Eucalypt cellulose } \\
\text { Fibres (\%) }\end{array}$ & $\begin{array}{c}\text { Mass starch } \\
(\mathbf{g})\end{array}$ & $\begin{array}{c}\text { Mass limestone } \\
(\mathbf{g})\end{array}$ & $\begin{array}{c}\text { Volume water } \\
(\mathbf{m l})\end{array}$ & $\begin{array}{c}\text { Mass cellulose } \\
\text { fibres }(\mathbf{g})\end{array}$ \\
\hline 01 & $5 \%$ & 47.5 & 47.5 & 100 & 5.0 \\
02 & $10 \%$ & 45.0 & 45.0 & 200 & 10.0 \\
03 & $15 \%$ & 42.5 & 42.5 & 250 & 15.0 \\
04 & $20 \%$ & 40.0 & 40.0 & 300 & 20.0 \\
05 & $30 \%$ & 35.0 & 35.0 & 400 & 30.0 \\
06 & $40 \%$ & 30.0 & 30.0 & 500 & 40.0 \\
\hline
\end{tabular}




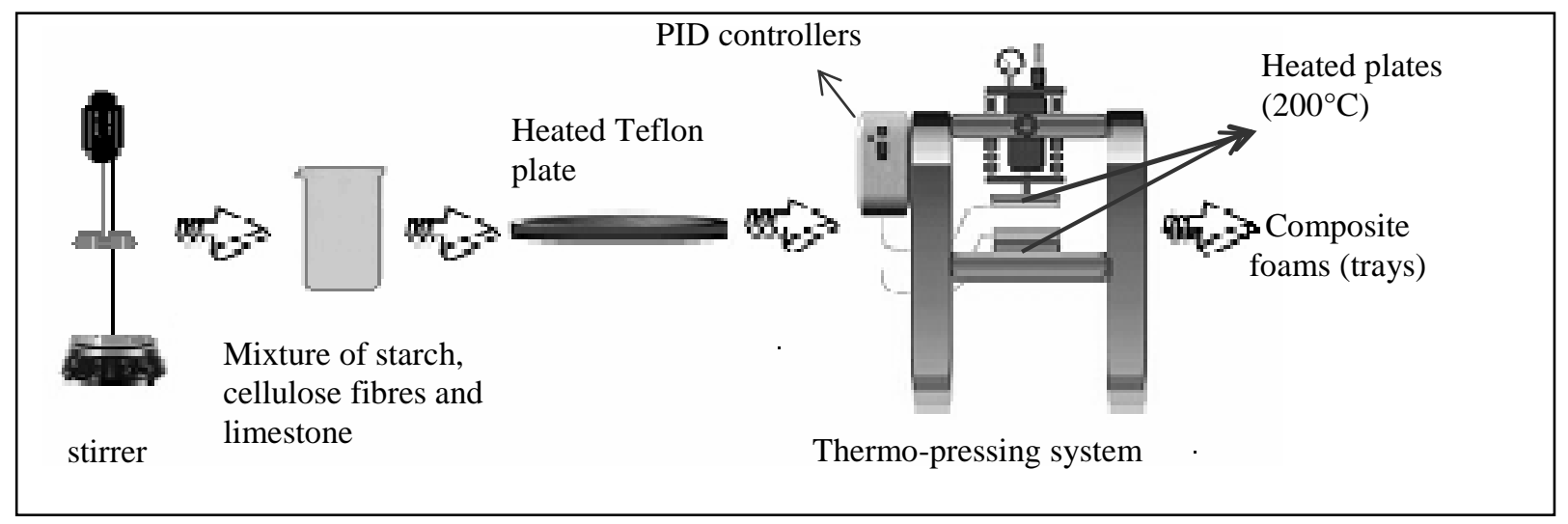

Figure 1 - Thermo pressing process used to obtain the foam trays.

A hydraulic machine with two heated plates controlled by PID controllers was used for the thermopressing process. The mould was heated and kept at $200-205^{\circ} \mathrm{C}$ between the two plates. The size of the mould cavity was $159 \mathrm{~mm}$ in length, $109 \mathrm{~mm}$ in width and $9.8 \mathrm{~mm}$ in thickness. The mixture was placed in the centre of the mould and covered by the lid. A pressure of $0.36 \mathrm{MPa}$ was applied to the mould for 3 minutes during the thermopressing process. During this the heated plates promoted the evaporation of water from the mixture and the steam produced promoted the formation of a porous structure and starch gelation.

\section{Conditioning}

The foam samples were conditioned for 5 days at $25^{\circ} \mathrm{C}$ with a relative humidity (RH) of $75 \%$, obtained with a saturated sodium chloride $(\mathrm{NaCl})$ solution. In order to compare results, all the samples were conditioned since water acted as a plasticizer, influencing the mechanical properties (Shogen et al, 1998; Larontonda et al., 2004; Soykeabkaew et al., 2004).

\section{Measurement of the mechanical properties}

To determine the mechanical properties of the foam trays, tensile strength tests were carried out in accordance with the ASTM D828-97 standard test method. A texture analyser TA-XT2i (Stable Micro System, England) with a 25N load cell was used to determine the mechanical properties of the foam samples, i.e., the tensile strength and relative deformation at break. Regular foam samples with dimensions of $25 \times 100 \mathrm{~mm}$ were fixed on the machine base to determine the tensile strength.
The tests were performed at $2 \mathrm{~mm} / \mathrm{s}$ to sample break (rupture). The thickness of each sample was assumed to be the average of four separate measurements determined with a digital micrometer (Mitutoyo, Japan).

The tensile strength curves were determined using 10 separate samples for each composition.

Puncture tests were also performed using a spherical probe $(21 \mathrm{~mm}$ diameter), which touched the sample, previously fixed in an annular space with a diameter of $80 \mathrm{~mm}$ (Fig. 2). The spherical steel probe was built specially for these mechanical tests. A spherical shape was used to avoid sharp edges that could influence the material break point. During the tests, the probe was moved through the sample, from top to bottom, with a speed of $1 \mathrm{~mm} / \mathrm{s}$, until $30 \mathrm{~mm}$ below the bottom of the sample. The load applied was $0.5 \mathrm{~N}$.

For this test, the relative deformations at break point were represented by equation 1 .

$$
\delta=\frac{\Delta L}{D}
$$

where $\Delta \mathrm{L}=$ vertical shift of the probe from the moment it touched the sample to the break point moment; $\mathrm{D}=$ diameter of sample under test, i.e., the base diameter.

\section{Scanning electron microscopy (SEM)}

Micrographs of the foam samples were obtained using a model XL-30 (Philips, Holland) scanning electron microscope. Before obtaining the micrographs, the foam samples were coated with a thin gold layer using a model SCD 005 (BALTEC, Swiss). All samples were examined using an accelerating voltage of $20 \mathrm{kV}$. 


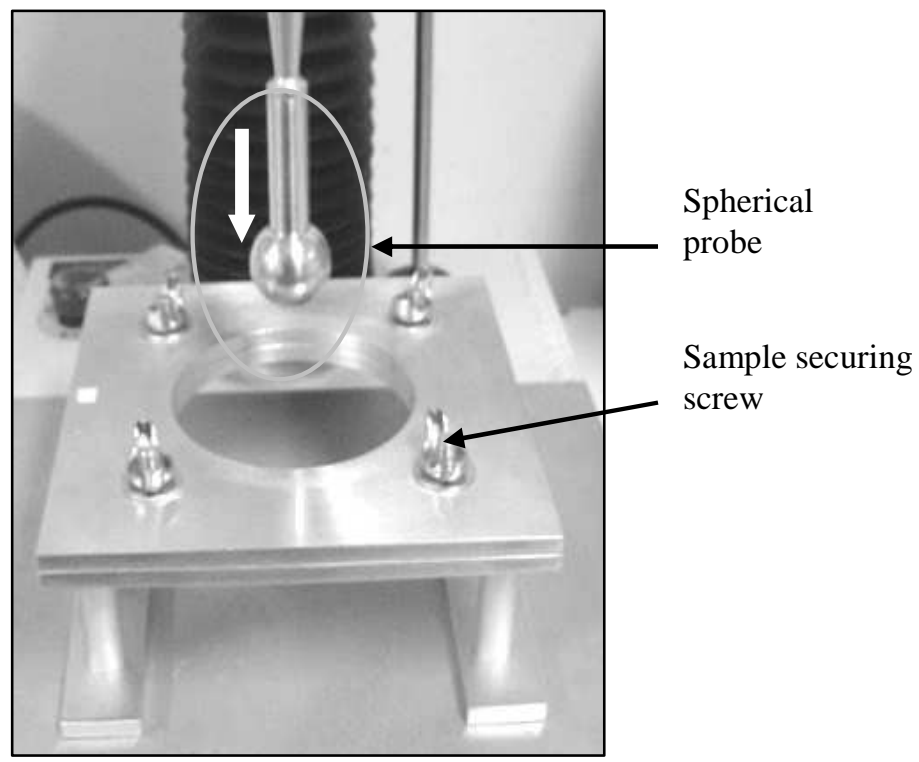

Figure 2 - Puncture tests: spherical probe and base used to secure the sample in the determination of the mechanical properties.

\section{Preliminary test using foam trays}

Prepared foam trays (11\% eucalypt cellulose fibres, 39\% limestone and $50 \%$ cassava starch) were used to pack foods such as ham (moisture of $71.4 \%, \mathrm{w} / \mathrm{w}$ ), cheese (moisture of $41.7 \%, \mathrm{w} / \mathrm{w}$ ) and frozen snacks. Two condition were tested: i) keeping food products in direct contact with foam trays surfaces (DC), and ii) avoiding direct contact between product and trays surfaces (WDC) that was achieved by coating the trays with a PVC film, as shown in Figure 3. In this case, the foam trays served only as a support, (similarly commercial EPS trays used for some applications in supermarkets). The packs were maintained at $5^{\circ} \mathrm{C}$ and $-20^{\circ} \mathrm{C}$ for 10 days. The appearance and mechanical properties of the foam trays were evaluated before and after the tests.

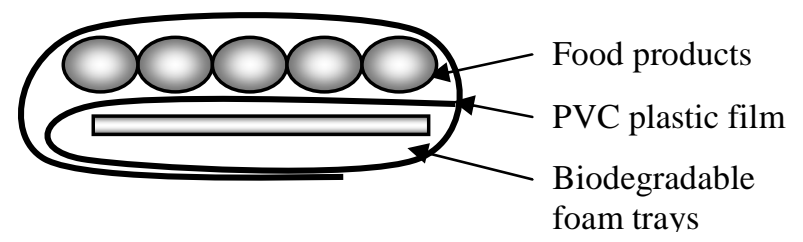

Figure 3 - Details of product packed without direct contact with foam trays.

\section{RESULTS AND DISCUSSION}

The foam trays were between white and cream in appearance, similar to the EPS foam trays analysed. Figures 4 to 6 show the results of mechanical tests carried out on the foam trays obtained with the different fibre concentrations. Figure 4 indicated that increases in the $\%$ fibre of the foam trays decreased their tensile strength due to a reduction in their density $\left(\mathrm{g} / \mathrm{cm}^{3}\right)$. Rupture occurred at 3.03 MPa (tensile strength) for foam trays containing $5 \%$ of cellulose fibres, twice the resistance presented by EPS commercial trays.

Figure 5 showed that the elongation at break didn't vary significantly with increase in the $\%$ of cellulose fibres. The values obtained were about $20 \%$ below those obtained for the commercial polystyrene foams used to produce the trays commonly used in supermarkets. 
The data of relative deformation at break $(\delta)$ obtained by puncture tests varied between 0.064 and 0.084 (Fig. 6). Samples of commercial polystyrene trays presented relative deformations of 0.124 , a value about $70 \%$ higher than the average value found for the foam trays prepared with $20 \%$ of cellulose fibres. Shogren et al. (1998) reported values close to 0.048 for the relative deformation of starch-based composite foams, a value lower than the values obtained in this study.

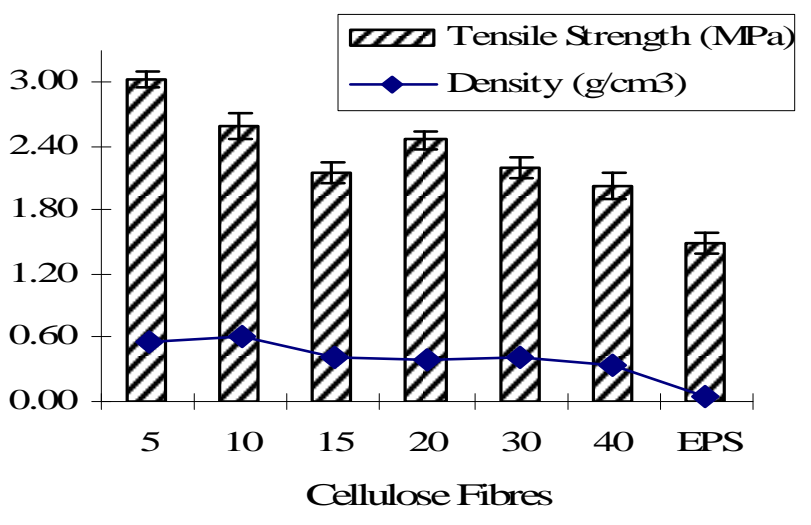

Figure 4 - Tensile strength and density of the cassava starch-eucalypt cellulose fibres-limestone foam trays.

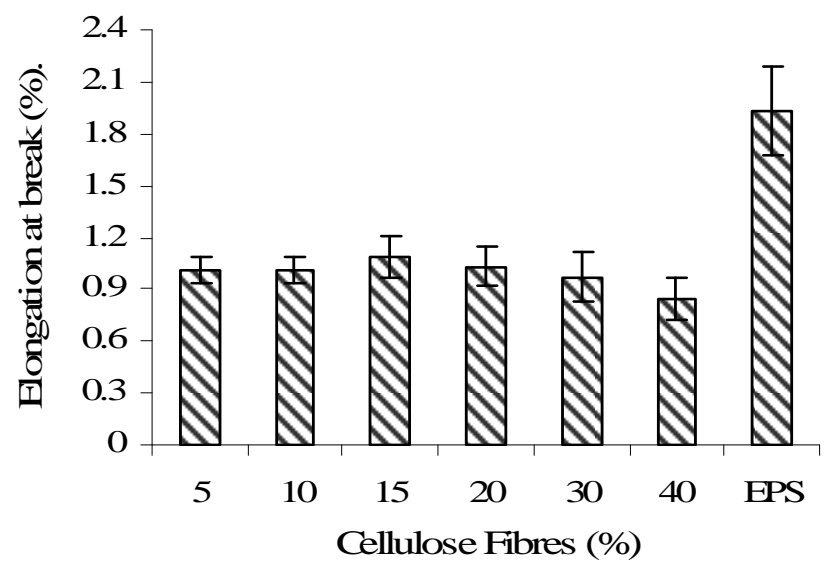

Figure 5 - Elongation at break of the cassava starch-eucalypt cellulose fibres-limestone foam trays.

Lawton et al. (2004) added aspen fibre to cornstarch foams to improve their mechanical properties. Foam trays were made with fibre contents ranging from 2.5 to $45 \%$ in the formulation, and their strength increased with increase in fibre content up to a limit of about $15 \%$, the tensile strength and deformation of the foam trays with fibre contents of $15 \%$ reached approximately $100 \mathrm{~N}$ and $30 \mathrm{~mm}$, respectively. Trays containing more than $30 \%$ of fibre were the weakest, probably due to a lack of uniformity in fibre distribution at these higher values. Soykeabkaew et. al (2004) added jute and flax fibres to cassava starch foam to improve their flexural strength and strain, making foam trays with fibre contents of 1,5 and $10 \%$. The addition of $10 \%$ jute fibres, with a moisture content of around 8-9\% improved the flexural strength, reaching a value of approximately $7.50 \mathrm{MPa}$, and improved the flexural strain, reaching a value of approximately $2 \%$, whereas the addition of $10 \%$ 
flax fibres, with a moisture content of around 8$9 \%$, reached values for flexural strength of approximately $6 \mathrm{MPa}$ and for flexural strain of approximately $2 \%$.

Glenn et al. (2001a) added softwood fibre to starch foams to improve their mechanical properties. Foam trays were made with fibre contents ranging from 6.7 to $22.2 \%$ in the formulation and moisture contents of $11 \%$, presenting values for flexural strength between 1.35 and $3.67 \mathrm{MPa}$ and values for tensile strain at the breaking point between 1.52 and $2.38 \%$.

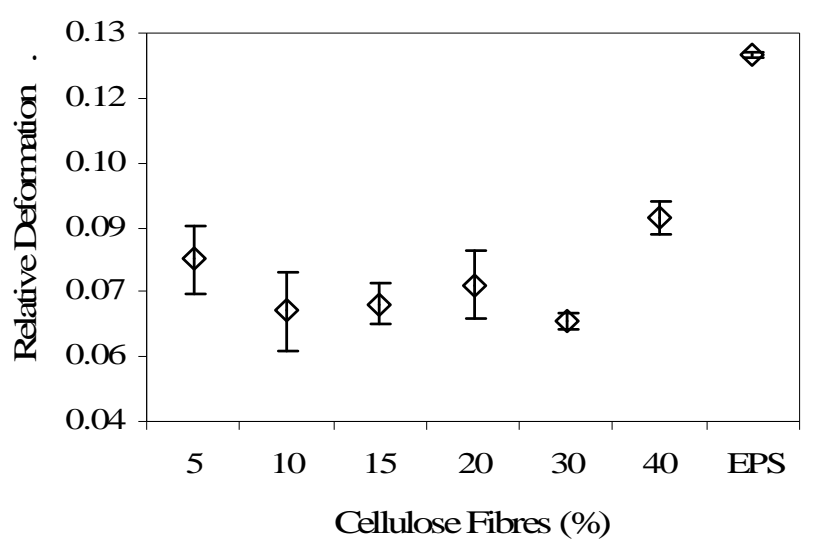

Figure 6 - Relative deformations obtained by puncture tests of cassava starch- eucalypt cellulose fibres-limestone foam trays.

The appearance of the foam samples without contact direct with food product (WDC) showed no problems for domestic use, indicating they could be used for commercial purposes. The ham produced exudates during storage, but the WDC foam trays showed no significant changes, maintaining their initial characteristics. Test with contact direct with product (DC) caused some softening to the foam samples, indicating that the trays were sensible to direct contact with moist foods. On the other hand, tests with and without direct contact performed with cheese and snacks showed no changes in the material during storage. Table 2 shows the values of tensile strength, elongation at break and relative deformation of the samples before and after the preliminary tests discussed above. Elongation at break and the relative deformation $(\delta)$ for DC tests were twice of WDC tests, due to the plasticizing effect of water. Trays tensile strength decreased 9 times in the DC tests when compared WDC tests. These results indicated that the trays properties needed to be improved in order to use them to pack moist foods. SEM micrographs showed the presence of some holes (cells) in the internal structure of the composites, caused by the evaporation of water from the mould (Fig. 7).

These cells were smaller in the limestone-fibrestarch foam trays than in the fibre-starch and limestone-starch foam trays. It has been reported that composite foams prepared with jute and flax fibres showed decreasing cell size with increasing fibre concentration (Soykeabkaew et. al, 2004).

Table 2 - Mechanical tests performed with foam trays before and after preliminary tests.

\begin{tabular}{lccc}
\hline Foam Trays Samples & $\begin{array}{c}\text { Tensile Strength } \\
\text { (MPa) }\end{array}$ & $\begin{array}{c}\text { Elongation at } \\
\text { break (\%) }\end{array}$ & $\begin{array}{c}\text { Relative } \\
\text { Deformation }\end{array}$ \\
\hline Before preliminary test & $3.265 \pm 0.112$ & $1.05 \pm 0.221$ & $0.0847 \pm 0.003$ \\
$\begin{array}{l}\text { After preliminary test food products in direct contact } \\
\text { with foam trays surfaces (DC) }\end{array}$ & $0.369 \pm 0.023$ & $2.168 \pm 0.179$ & $0.1355 \pm 0.005$ \\
$\begin{array}{l}\text { After preliminary test avoiding direct contact between } \\
\text { product and trays surfaces (WDC) }\end{array}$ & $3.254 \pm 0.329$ & $1.391 \pm 0.269$ & $0.0822 \pm 0.009$ \\
\hline
\end{tabular}



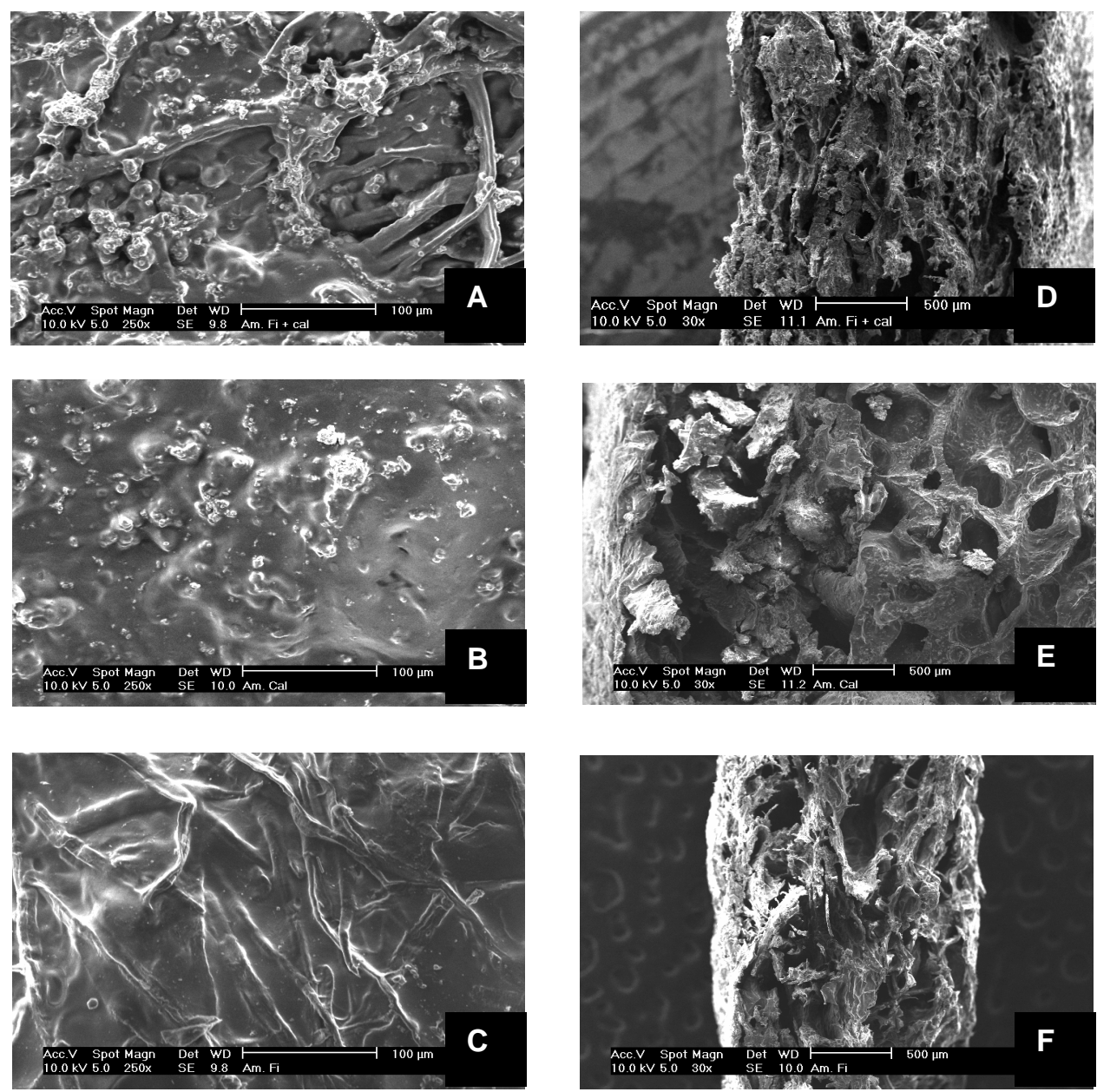

Figure 7 - SEM of the foam trays (A) Surface of cassava starch-limestone-eucalypt cellulose fibre foam trays (B) Surface of cassava starch-limestone foam trays (C) Surface of cassava starch-eucalypt cellulose fibre foam trays (D) Cross-section of cassava starchlimestone-eucalypt cellulose fibre foam trays (E) Cross-section of cassava starchlimestone foam trays (F) Cross-section of cassava starch-eucalypt cellulose fibre foam trays.

\section{CONCLUSIONS}

The composite foam trays prepared from cassava starch, eucalypt cellulose fibres and limestone presented properties that allowed their use for packing dry foods. They presented higher tensile strength, but much lower flexibility than commercial EPS trays. The coating of foam trays with PVC films could be an alternative to extend their use to all kind of products and reduce the use of EPS and other petroleum-based trays. The commercial use of these materials would need additional study considering specific quality and safety needs of each food.

\section{RESUMO}

Amido de mandioca, calcário dolomítico e fibras celulósicas de eucalipto foram usados para preparar bandejas biodegradáveis que podem ser usadas como embalagens para alimentos. A influência da concentração de fibras na formulação dos compostos foi investigada, usando $5,10,15$, 20, 30 e $40 \%$ de fibras. Os resultados indicaram que o aumento na concentração de fibras celulósicas promove uma diminuição na densidade e na resistência a tração das amostras. A tensão na ruptura para as bandejas contendo $5 \%$ de fibras celulósicas foi de 3,03 MPa, enquanto as bandejas 
comerciais de poliestireno expandido (EPS) usadas para embalagens alimentícias em supermercados apresentaram uma tensão de $1.49 \mathrm{MPa}$. A elongação na ruptura das bandejas obtidas neste trabalho variou ligeiramente com o aumento da concentração de fibra celulósica, os valores são aproximadamente $20 \%$ mais baixos do que a elongação na ruptura observada para bandejas comerciais de poliestireno expandido. Os resultados indicaram que as propriedades das bandejas devem ser melhoradas na utilização de embalagem de alimentos úmidos. Assim os materiais desenvolvidos neste trabalho representam uma possível alternativa para o uso de bandejas de EPS para embalar alimentos secos. As propriedades das bandejas necessitam ser melhoradas para sua utilização com alimentos úmidos.

\section{REFERENCES}

Andersen P. J., Hodson S. K. (2001a), US Patent $\mathrm{n}^{\circ}$ 6,231,970. Thermoplastic starch compositions incorporating particulate filler component.

Andersen P.J., ONG S., Christensen B. J., Hodson S. K. (2001b), US Patent $\mathrm{n}^{\circ} 6,168,857$. Compositions and methods for manufacturing starch-based compositions.

ASTM (1997), Standard test method for tensile properties of paper and paperboard using constantrate-of-elongation apparatus, D828-97.

Da Róz, A. L.; Carvalho, A. J. F.; Morais, L. C.; Curvelo, A. A. S. (2001), Thermal behavior and moisture absorption of plastic starch with glycols (in Brazilian). Paper presented in $6^{\circ}$ Congresso Brasileiro de Polímero, Gramado, RS.

Glenn G. M., Orts W. J., Nobes G. A. R. (2001a), Starch, fibre and $\mathrm{CaCO} 3$ effects on the physical properties of foams made by a baking process. Ind. Crops Prod., 14, 201-212.

Glenn G. M., Orts W. J. (2001b), Properties of starchbased foam formed by compression/explosion processing. Ind. Crops Prod., 13, 135 - 143

Gould, J.M., Gordon, S.H., Dexter, L.B., Swanson, C.L. (1990), Biodegradation of starch-containing plastics. ACS Symp. Ser. Am. Chem. Soc., 433, 65-75.
Larotonda F.D.S., Matsui K.N., Soldi V., Laurindo J. B., 2004. Biodegradable Films Made from Raw and Acetylated Cassava Starch. Brazilian Arch of Biol. Techn. 47, 477-484.

Lawton J. W., Shogren R.L., Tiefenbacher K.F. (1998), Structure and morphology of baked starch foams. Polymer, 25, 6649-6655.

Lawton, J. W., Shogren, R. L., Tiefenbacher, K. F. (2004), Aspen fibre addition improves the mechanical properties of baked cornstarch foams. Ind. Crops Prod., 19, 41-48.

Leite P. J. F., Lima A. A. G., Lima A. M. F. Nascimento F. R. (1999), Biodegradable polystyrene for dismissable packings: development of the blend for the cassava starch incorporation. TECBAHIA Revista Baiana de Tecnologia, 14, 126 - 130.

Matsui, K.N., Larontonda, F. D. S., Paes, S. S., Luiz, D. B., Pires, A. T. N., Laurindo, J. B. (2004), Cassava bagasse-Kraft paper composites: analysis of influence of impregnation with starch acetate on tensile strength and water absorption properties. Carbohydr. Polymers, 55, 237-243.

Shogren R. L., Lawton J. W., Doane W. M., Tiefenbacher K. F. (1998), Structure and morphology of baked starch foams. Polymer, 39, 6649-6655.

Shogren R.L., Lawton J. W., Tiefenbacher K.F. (2002), Baked starch foams: starch modifications and additives improve process parameter, structure and properties. Ind. Crops Prod., 16, 69-79.

Soykeabkaew N., Supaphol P., Rujiravanit R. (2004), Preparation and characterization of jute and flax reinforced starch-based composite foams. Carbohydr. Polymers, xx, 1-11.

Tiefenbacher K. F. (1993), Starch-based foam materials - use and degradation properties. J. Macromol. Sci. Pure Appl. Chem., A30, 727 - 731.

Vinhas G. M., Lima S. M., Santos L. A., Lima M. A. G. A., Almeida Y. M. B. (2007), Evaluation of the types of starch for preparation of LDPE/starch blends. Braz. Arch. Biol. Techn. 50, 361-370.

Received: April 12, 2007; Revised: January 22, 2008; Accepted: May 08, 2009. 